\title{
ANÁLISE AMBIENTAL COMO SUBSÍDIO AO PLANEJAMENTO URBANO: O CASO DE BOA ESPERANÇA (MG)
}

\author{
ENVIRONMENTAL ASSESSMENT TO SUPPORT THE URBAN PLANNING: \\ BOA ESPERANÇA (MG) CASE
}

Larissa Gischewski Guimarães*

Clibson Alves dos Santos**

\section{RESUMO}

A área de estudo do presente trabalho compreende as bacias hidrográficas urbanas da sede do município de Boa Esperança (MG), que apresentam diversos problemas socioambientais decorrentes da ação antrópica. Poluição, assoreamento e eutrofização dos córregos e ocupação desordenada das áreas de preservação permanente são os principais problemas observados. Na área de estudo, formou-se o Lago dos Encantos, porção do reservatório da usina hidrelétrica de Furnas muito utilizada para recreação, atividades esportivas e pesca. Este estudo realizou a análise ambiental das bacias hidrográficas citadas por meio da análise de aspectos qualitativos dos corpos hídricos, do uso do solo, da degradação ambiental e das áreas sujeitas a enchentes e inundações. Os resultados mostram que a urbanização impactou as Áreas de Preservação Permanente (APP), prejudicando a qualidade ambiental e sanitária desses ambientes, resultando em problemas que podem afetar diretamente a saúde pública. A partir dessa análise, recomendou-se o estabelecimento de ações corretivas e preventivas, como a revitalização dos ambientes, a criação e ampliação de parques municipais, criação de ciclovias e atividades educativas que envolvam a comunidade. Para que essas ações tenham êxito devem-se incluir diretrizes relacionadas à conservação ambiental no processo de revisão do plano diretor municipal. Essa iniciativa é fundamental para que o planejamento urbano seja integrado ao planejamento ambiental.

Palavras-chave: Análise ambiental. Bacias hidrográficas urbanas. Áreas de Preservação Permanente.

\section{ABSTRACT}

The study area comprises the urban watersheds in Boa Esperança (MG), which have several social and environmental problems due to human action. Pollution, siltation and eutrophication of streams, along with the disorderly occupation of permanent preservation areas are the main problems observed. In the study

* Bióloga pela Universidade Federal de Alfenas (Unifal-MG). Mestranda em Ciências Ambientais na Universidade Federal do Rio de Janeiro (UFRJ). Analista ambiental na Empresa Pública Municipal de Saneamento (ESANE) de Macaé (RJ). Avenida XV de Outubro, 12, 37170-000, Centro, Boa Esperança, MG, Brasil.

larissagguimaraes@yahoo.com.br

** Geógrafo pela Universidade do Tocantins (Unitins). Professor adjunto III no Instituto de Ciências da Natureza da Universidade Federal de Alfenas (ICN-Unifal). Unidade Educacional II. Avenida Jovino Fernandes Sales, 2.600, 37130-000, Santa Clara, Alfenas, MG, Brasil.

clibsonsantos@gmail.com 
area formed the Encantos lake, portion of the Furnas Hydroelectric Power Plant reservoir, widely used for recreation, sports and fishing activities. This study conducted environmental analysis of the mentioned river basins, through the analysis of qualitative aspects of stream, land use, environmental degradation and areas subject to flooding. The results show that urbanization affected the Areas of Permanent Preservation, damaging the environmental and health quality of these environments, resulting in issues that may directly affect public health. From this analysis it was recommended the establishment of corrective and preventive actions, such as the revitalization of the environment, the creation and expansion of municipal parks, creating bicycle paths and educational activities involving the community. For these actions to succeed, the review process of the master plan, should include guidelines related to environmental conservation. This initiative is essential for urban planning is integrated with environmental planning.

Keywords: Environmental analysis. Urban watersheds. Areas of Permanent Preservation.

\section{INTRODUÇÃO}

Com o advento da Lei $n^{\circ}$ 11.445/07, que estabeleceu o Plano Nacional de Saneamento Básico (PNSB), surgiu o conceito de saneamento básico como o conjunto de serviços, infraestrutura e instalações de abastecimento de água, esgotamento sanitário, limpeza urbana, manejo de resíduos sólidos e drenagem de águas pluviais urbanas. (BRASIL, 2007).

As atividades industriais e imobiliárias têm causado danos à qualidade ambiental de nascentes e rios, principalmente daqueles em áreas urbanas. $O$ impacto ambiental mais danoso sofrido pelos rios urbanos é a poluição e/ou contaminação provocada pelo despejo de esgotos não tratados e pelo lançamento de resíduos sólidos às margens dos cursos d'água - que, além de degradar a qualidade das águas, podem causar danos diretos à saúde das populações ribeirinhas, constituindo-se num problema socioambiental. A qualidade da água, segundo Merten e Minella (2002), não se trata de estado de pureza, mas, sim, de características químicas, físicas e biológicas da mesma, pelas quais são estipuladas diferentes finalidades para uso. Para definir tal qualidade é utilizada uma série de parâmetros representativos dessas características. (BILICH; LACERDA, 2005).

As bacias hidrográficas da sede municipal de Boa Esperança (MG) apresentam os problemas mencionados, porém, com agravantes, principalmente por estarem inseridas no contexto do reservatório da usina hidrelétrica de Furnas, situado na bacia do rio Grande -, que forma na cidade o Lago dos Encantos, muito utilizado pela comunidade local como balneário, para a prática de esportes náuticos, pesca, sendo importante área de lazer e gerador de renda por intermédio do turismo.

A precariedade do saneamento ambiental, a ocupação desordenada das margens dos córregos e a ausência de sistema de coleta e tratamento de esgoto na área urbana de Boa Esperança são fatores de risco à saúde da comunidade local e, também, causas de danos ambientais. Um dos problemas fundamentais é a ocorrência de doenças de veiculação hídrica, maximizada em regiões de baixa renda, onde as condições de higiene são inadequadas. Nesse contexto, fica claro que os estudos direcionados a saneamento ambiental e à avaliação da qualidade ambiental das bacias hidrográficas urbanas são importantes, pois trata-se de um problema de 
saúde pública que reflete diretamente em aspectos sociais, econômicos, ambientais e culturais da comunidade.

Este trabalho tem como objetivo compreender a situação ambiental dos recursos hídricos do perímetro urbano do município e colaborar na indicação de iniciativas que visem à melhora da qualidade de vida - e, consequentemente, trazer benefícios ao meio ambiente. Uma análise da situação será realizada por meio de identificação das condições ambientais dos córregos urbanos e das áreas sujeitas a inundações. Com isso, espera-se contribuir com as discussões sobre a melhoria das condições ambientais dos 48 municípios no entorno do reservatório da usina hidrelétrica de Furnas e auxiliar num modelo de planejamento que integre questões ambientais e ordenamento territorial urbano.

\section{LOCALIZAÇÃO DA ÁREA DE ESTUDO}

O município de Boa Esperança localiza-se a $21^{\circ} 05^{\prime}$ de latitude Sul e $45^{\circ} 33^{\prime}$ de longitude Oeste, com altitude de 775 metros. A área de estudo compreende a porção urbana dos córregos Marimbondo, Maricota e Cascavel, que deságuam no Lago dos Encantos (figura 1).

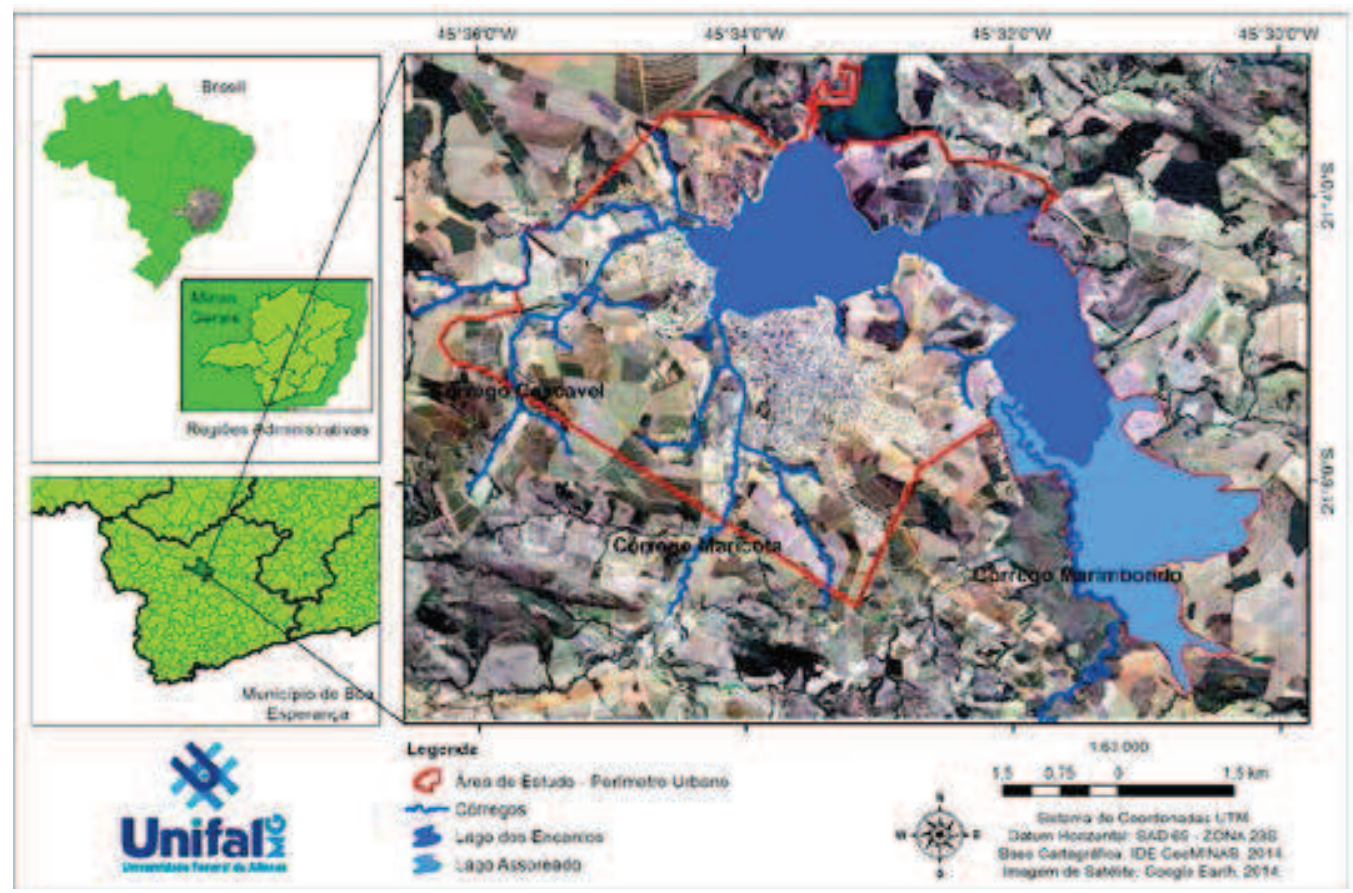

Figura 1 Localização da área de estudo no contexto da Região Administrativa do Sul de Minas Gerais, Brasil. Fonte: Clibson Alves dos Santos. A partir de imagens aéreas do Google Earth (2013) e de bases cartográficas do Ide-Geominas - 2014.

Segundo o Censo Demográfico 2010, o município tinha população total de 38.516 mil habitantes, sendo que 83,6\% (32.191 mil habitantes) moravam na área urbana e 
16,4\% (6.325 mil habitantes) na zona rural. Em 2013 a população do município teve aumento de 4,2\%, sendo estimada em 40.018 mil habitantes. (IBGE, 2010).

$O$ Lago dos Encantos encontra-se no centro da cidade, formado pelo represamento do reservatório da usina hidrelétrica de Furnas - a partir da construção de um dique para manter seu nível constante e impedir que descargas de esgoto voltem em direção à cidade. O lago é muito utilizado como atrativo turístico e tem funções de balneário para a população local. Esse sistema hidrográfico faz parte da Bacia Hidrográfica do rio Grande, afluente das cabeceiras da bacia do rio Paraná, no Estado de Minas Gerais.

\section{REVISÃO BIBLIOGRÁFICA}

O uso adequado dos recursos naturais e ambientais está em pauta, há tempos, nas grandes conferências promovidas pela ONU (Organização das Nações Unidas). Nos últimos anos, devido à crise hídrica no Sudeste brasileiro, o tema tem sido muito comum em discussões no contexto nacional e regional.

Entre os diversos tipos de recursos naturais, os recursos hídricos ganham destaque devido à sua vital importância em todas as atividades humanas, sejam econômicas, sociais ou até mesmo religiosas. (FELDMANN, 1992). A água influi na qualidade de vida de várias formas, tornando-se indispensável à saúde humana. Segundo Yahn (1999), a água é necessária tanto no meio urbano quanto no rural - fator crítico na produção dos setores industriais e agrícolas - sendo responsável por manter a sustentabilidade de ecossistemas aquáticos e terrestres. No final da década de 1970, iá se afirmava que grandes aspirações e desafios em busca de uma vida melhor para a humanidade demandariam o uso crescente da água. É impossível elevar o padrão de vida sem aumento quantitativo e qualitativo da água. (MAGEED, 1978). Por conseguinte, a ideia de conciliar o relacionamento do homem com o meio ambiente transforma-se em prerrogativa a ser seguida para alcançar as bases da construção do desenvolvimento sustentável, sobretudo ao que se refere às várias formas de uso da água.

Segundo a Lei no 9433/97 (BRASIL, 1997), que institui a Política Nacional de Recursos Hídricos, a gestão das águas deve ser feita no âmbito das bacias hidrográficas. Conforme Santos (2004), as bacias hidrográficas são facilmente reconhecidas e caracterizadas - condição favorável para o manejo e o gerenciamento integrado. Visto que toda a dispersão humana está intimamente ligada às bacias hidrográficas, qualquer impacto sobre elas não só afetará o ecossistema ao redor, mas também a sociedade, que se beneficia de seus recursos naturais.

A discussão sobre recursos hídricos encontra-se em posição de elevado grau de importância, devido, também, às mudanças climáticas observadas na última década em todas as regiões do mundo. A gestão das águas passa a ter papel estratégico nos ambientes urbanos, considerando os sistemas de drenagem, construídos para disciplinar as águas pluviais, e os componentes das bacias hidrográficas, que, quando em equilíbrio, podem tanto minimizar os efeitos das chuvas, como aumentar a disponibilidade hídrica. 


\section{MATERIAL E MÉTODOS}

A análise ambiental das drenagens urbanas do município de Boa Esperança foi realizada a partir do levantamento qualitativo das condições ambientais de sete pontos da área de estudo, identificando as condições ambientais dos córregos que deságuam no Lago dos Encantos, considerando aspectos como coloração, odor, presença de resíduos sólidos, lançamento de efluentes urbanos, processos erosivos, assoreamento, eutrofização e ocorrência de mata ciliar. Além disso, fez-se um levantamento das áreas sujeitas a ocorrências de enchentes e inundações.

Para a compreensão das alterações antrópicas na área urbana, realizou-se uma análise do uso e ocupação do solo urbano, utilizando imagens de alta resolução espacial disponíveis no Google Earth. (GOOGLE EARTH, 2013). Foi produzido um mosaico (por meio do programa Image Composite Editor - Microsoft 2013) a partir de imagens capturadas do sistema e posteriormente recortadas. Considerando essas imagens, procedeu-se ao mapeamento do uso e ocupação do solo na área de estudo mediante interpretação visual e verificação em campo, tendo como base o método sistemático de interpretação de imagens descrito por Moreira (2005), via programa ArcGIS 10.2. (ESRI, 2014).

Nessa etapa, foram identificados os tipos de cobertura vegetal presentes nas Áreas de Preservação Permanente (APPs) às margens dos cursos d'água, numa faixa de 30 metros, conforme o Código Florestal Brasileiro (BRASIL, 2012), haja vista que os córregos apresentam largura inferior a 10 metros. Essa análise teve como objetivo verificar eventuais conflitos entre a preservação das matas ciliares e as alterações antrópicas nos ambientes. Para a delimitação das APPs, utilizou-se a ferramenta buffer, e, para o recorte do uso e ocupação do solo, a ferramenta clip, do programa ArcGIS 10.2. (ESRI, 2014).

\section{RESULTADOS E DISCUSSÃO}

\subsection{ANÁLISE AMBIENTAL}

De modo geral, registraram-se, nos pontos de análise (figura 2), as seguintes características: edificações nas planícies de inundação; pastoreio de bovinos próximo dos cursos d'água; loteamentos aprovados em áreas que deveriam ser destinadas à preservação das matas ciliares; resíduos sólidos às margens dos córregos; processo acelerado de eutrofização artificial em porções do lago.

No ponto 1, localizado no terraço fluvial do córrego Maricota (figura 2), foi verificada a ocorrência de residências, fábrica de tijolos/telhas (figura 3A) e presença de aterros clandestinos constituídos de restos de construção (terra e entulho) na planície de inundação do curso d'água. O ponto 2 tem como referência a entrada da fazenda Santo Agostinho, onde se verificou, também, a presença de aterros formados por restos de construção - terra, entulho e resíduos sólidos (figura 3B) - de residências e áreas de pastagem próximo do curso d'água, nos limites das áreas APPs. 


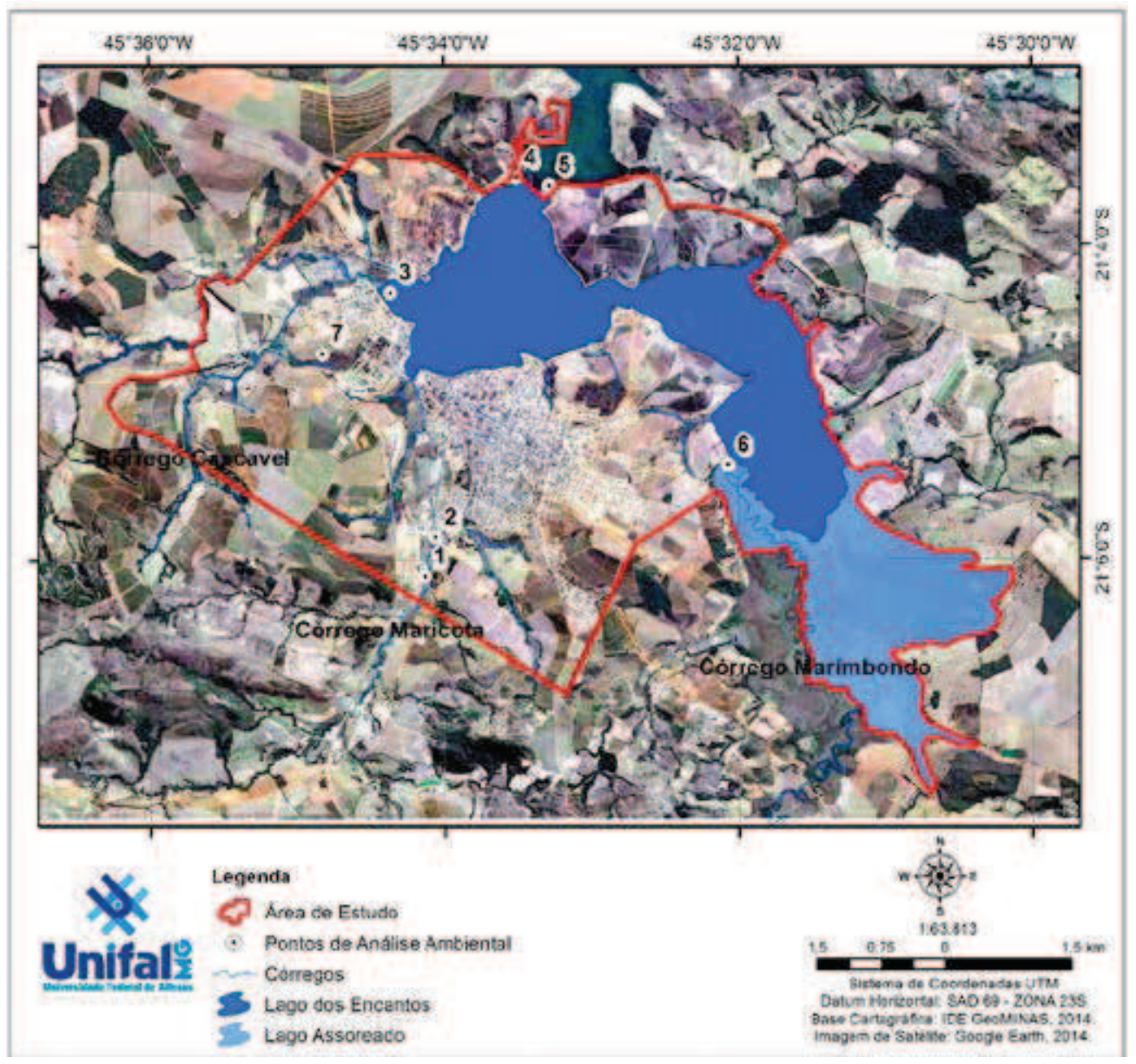

Figura 2 Pontos analisados na área de estudo no contexto do perímetro urbano do município de Boa Esperança, MG, Brasil.

Fonte: Clibson Alves dos Santos. A partir de imagens aéreas do Google Earth - 2014.

As características observadas nos dois pontos evidenciam problemas de degradação decorrentes da falta de planejamento e fiscalização do uso do solo urbano. A inserção de indústria de cerâmica, residências e aterros clandestinos próximo dos córregos provoca a contaminação das águas e instabiliza a dinâmica dos fluxos fluviais e pluviais, intensificando o escoamento superficial e reduzindo a infiltração das águas. Esses ambientes têm função hidrológica relacionada ao transbordamento natural dos córregos, porém a ocupação desordenada dessas áreas causa desequilíbrio nos processos naturais, resultando em ocorrência e intensificação de enchentes e em polvição dos corpos hídricos.

O ponto 3 (figuras 2 e 4) é um trecho do córrego Cascavel, no qual se observa grande concentração de plantas macrófitas aquáticas, resultante do processo de eutrofização. Segundo Galli e Abe (2014, p. 7):

A eutrofização de corpos de águas interiores consiste no enriquecimento com nutrientes, principalmente fósforo e nitrogênio, que entram como solutos e se transformam em 
partículas orgânicas e inorgânicas. O crescimento acelerado e a maior abundância de plantas aquáticas causam, frequentemente, deterioração da qualidade hídrica e crescimento de grandes volumes de algas, inclusive de cianobactérias potencialmente tóxicas, tornando-se um risco à saúde do ecossistema, além de implicar em aumento no custo do tratamento da água para abastecimento.

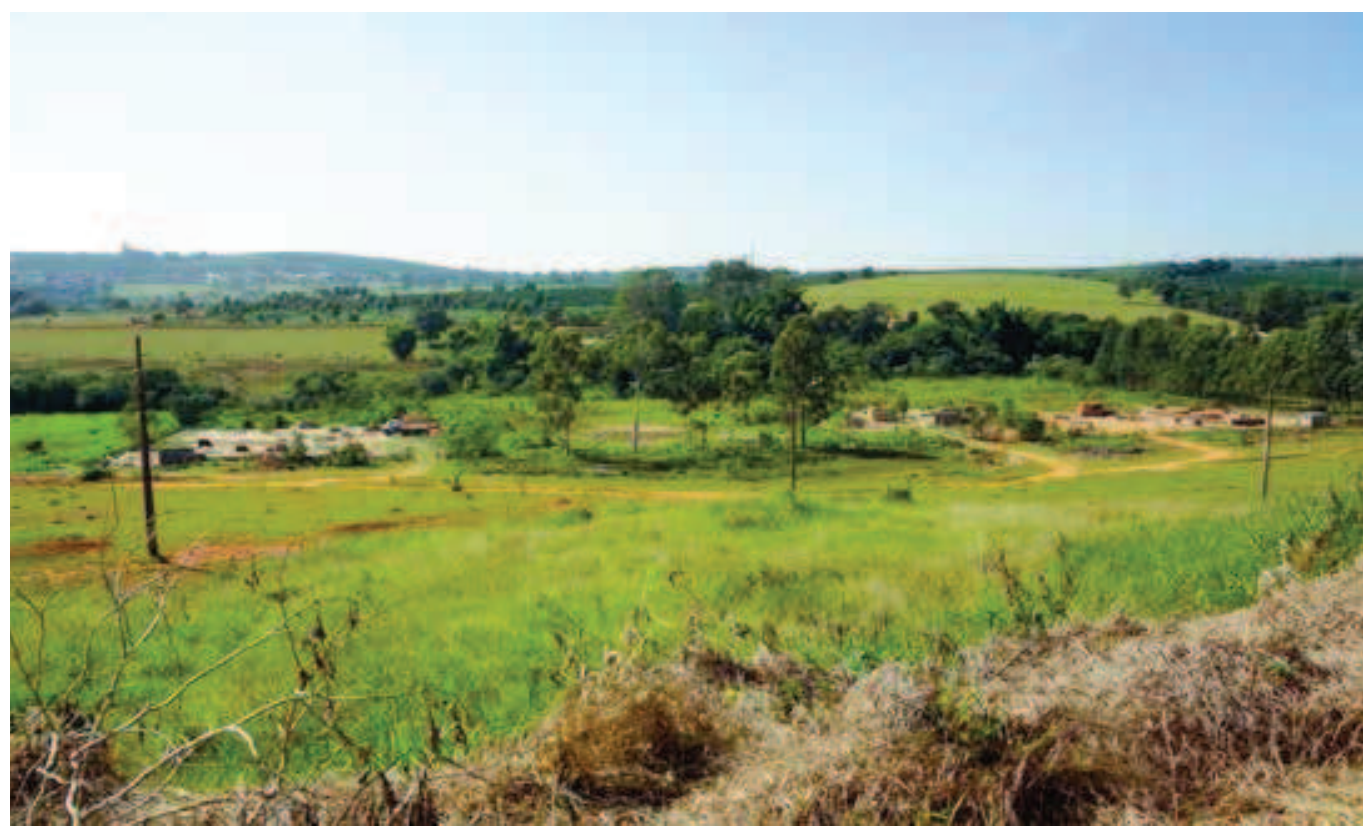

Figura 3A Edificações na planície de inundação do córrego Maricota (ponto 1). Foto: Larissa Gischewski Guimarães - mar. 2012

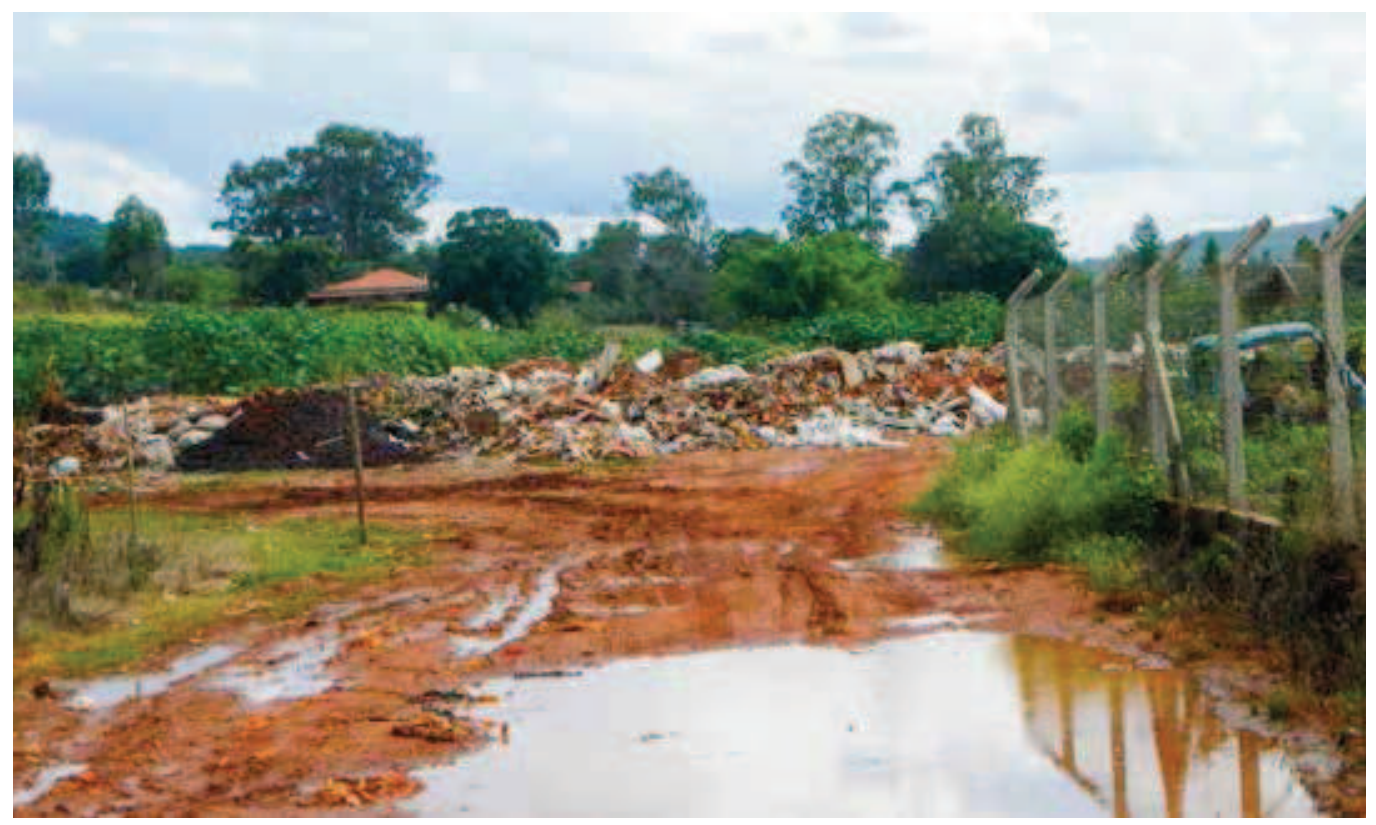

Figura 3B Aterros clandestinos com restos de construção e resíduos sólidos (ponto 2). Foto: Larissa Gischewski Guimarães - mar. 2012 
$\mathrm{Na}$ área de estudo, esse processo ocorre devido ao acúmulo de matéria orgânica proveniente do lançamento de afluentes domésticos não tratados e pela deposição de sedimentos transportados pela erosão laminar atuante nas encostas.

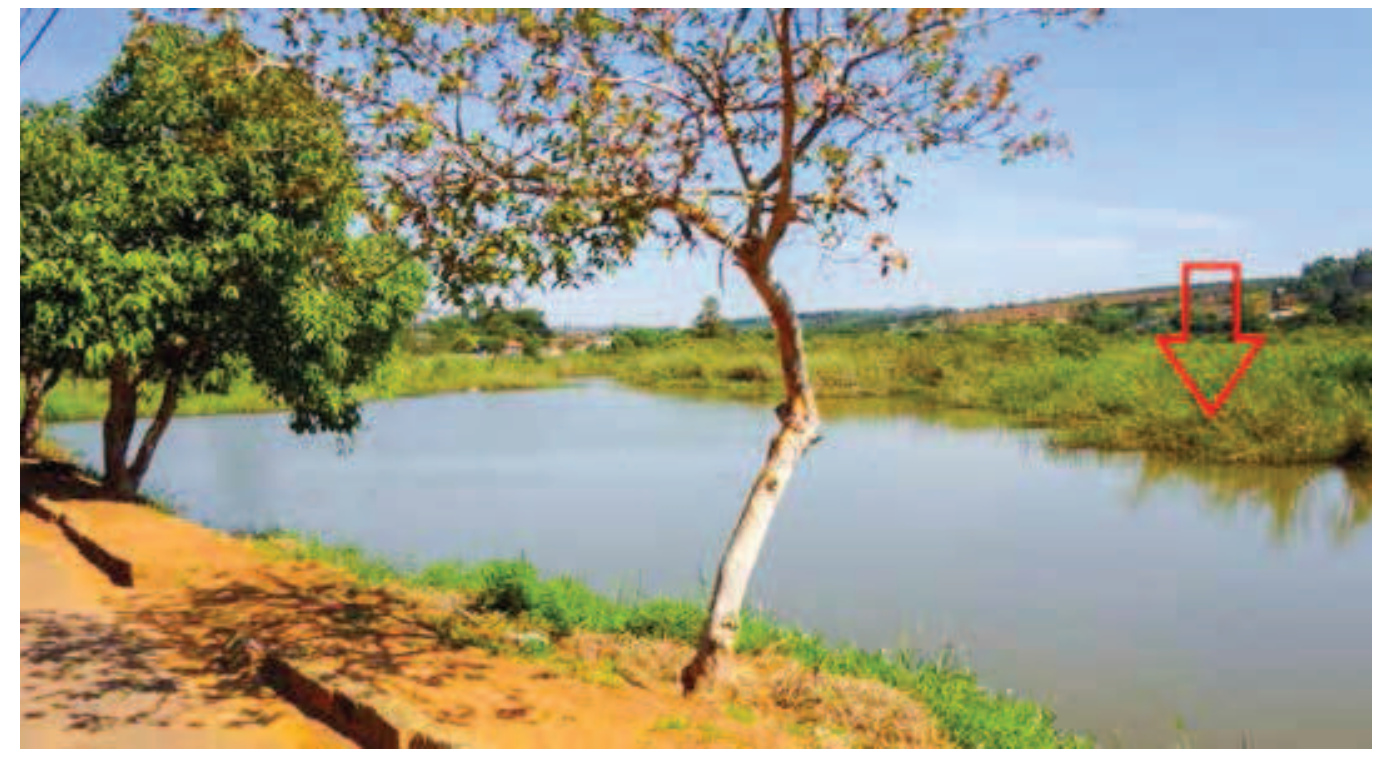

Figura 4 Porção eutrofizada (seta vermelha) no Lago dos Encantos (ponto 3) com a presença de lançamento de esgoto doméstico não tratado e acúmulo de sedimentos. Foto: Larissa Gischewski Guimarães - mar. 2012

Próximo do ponto 3, há um balneário utilizado por moradores do entorno. $\bigcirc$ uso do lago por banhistas nessa porção do reservatório pode resultar na contaminação dos usuários devido à grande presença de esgoto doméstico no ambiente. Além disso, a comunidade utiliza esse local para pesca artesanal, intensificando o problema, pois o consumo dos peixes pode causar doenças.

Os pontos 4 e 5 (figuras 2 e $5 \mathrm{~A}$ ) localizam-se perto do dique construído para controlar o nível do reservatório de Furnas, formando o Lago dos Encantos na área urbana. Sobre o dique, foi construída uma ponte de acesso a zona rural (figura 5A). No local, verifica-se a ocorrência de forte odor, devido ao despejo de esgoto após a barragem, ao pastoreio de bovinos e à grande concentração de resíduos sólidos. Essas características conferem condições higiênico-sanitárias inadequadas, e podem resultar em risco à saúde da população.

Apesar de o ambiente estar visivelmente polvído, observa-se que a pesca artesanal é prática comum nessa localidade. As águas, tanto da porção que antecede o dique, como após o barramento, apresentam forte odor de esgoto e presença de resíduos sólidos. A ocorrência de peixes pode ser considerada um bioindicador de que o estágio de polvição ainda é mediano, porém a contaminação dos peixes torna-se inevitável em tais condições, pois as águas apresentam fortes indícios de ocorrência de nitratos, nitritos, agentes bacterianos e virais, devido ao lançamento de esgoto não tratado e resíduos sólidos presentes no corpo d'água. 


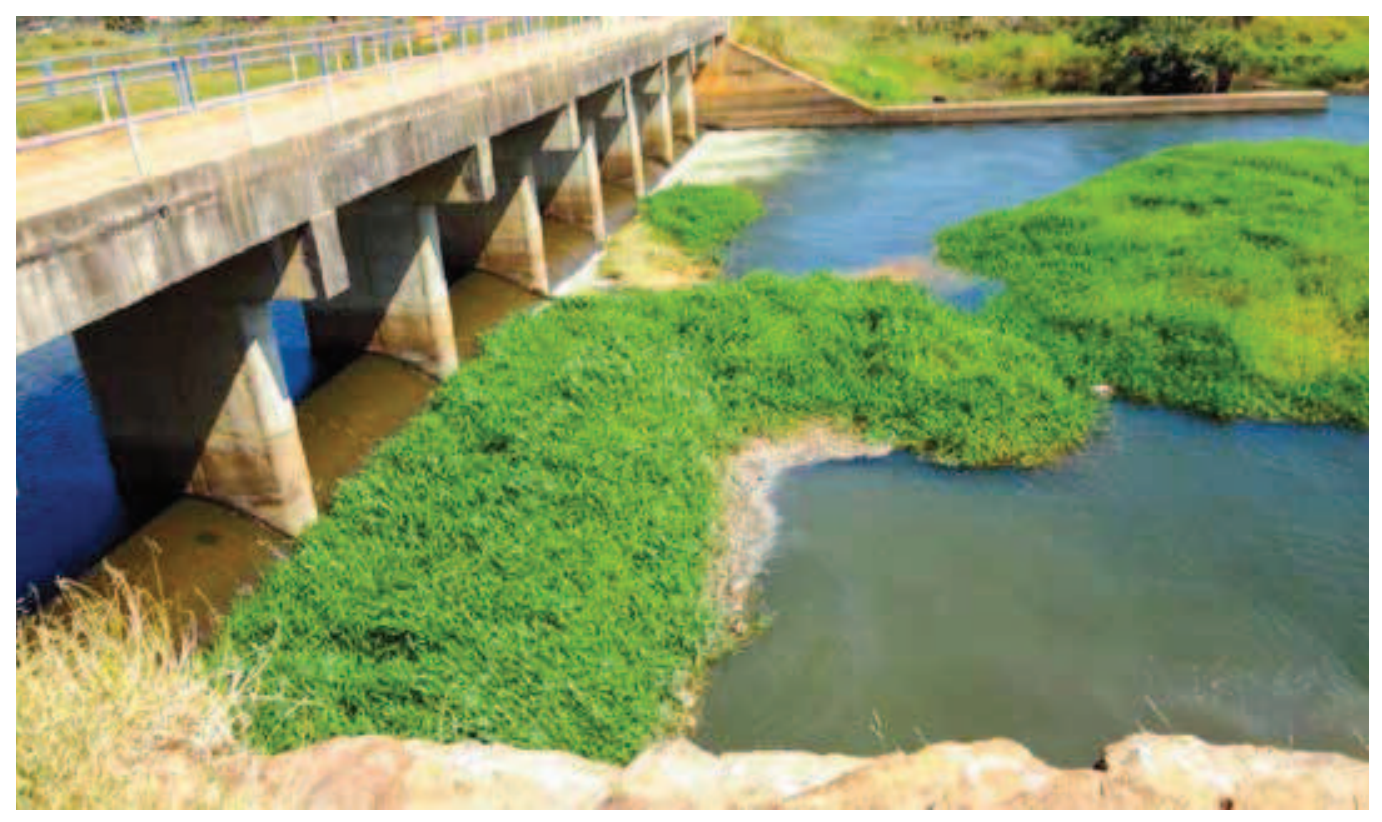

Figura 5A Esgoto e resíduos sólidos próximo do dique (pontos 4 e 5).

Foto: Larissa Gischewski Guimarães - mar. 2012

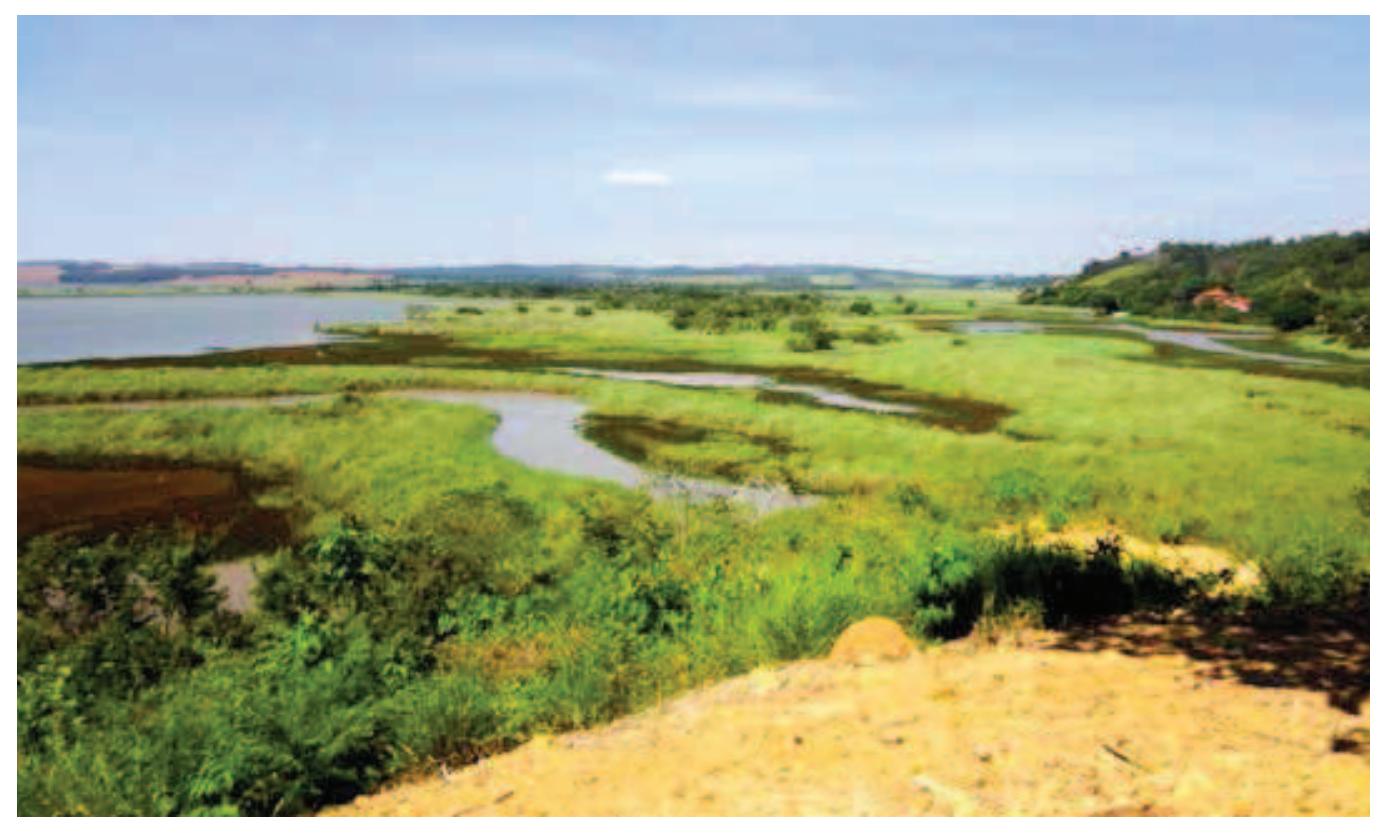

Figura 5B Porção eutrofizada e assoreada no Lago dos Encantos (ponto 6).

Foto: Larissa Gischewski Guimarães - mar. 2012

O ponto 6 (figuras 2 e 5B) localiza-se numa porção do lago bastante eutrofizada pela presença de plantas macrófitas. No contexto da área de estudo, esse ambiente apresenta o estágio mais avançado de eutrofização e assoreamento. Além das espécies aquáticas, nota-se a presença de árvores de médio porte, evidenciando que o processo de assoreamento é antigo e formou uma camada espessa de material sedimentar. 
Segundo Smith e Schindler (2009), em ambientes eutrofizados são comuns problemas de crescimento de espécies de algas potencialmente tóxicas, bentônicas e epifíticas, mortandade de peixes, redução da diversidade de espécies, transparência da água, oxigênio dissolvido e valor estético do corpo de água.

No ponto 7 (figura 2), observa-se que na APP do córrego Cascavel ocorre exploração de solo orgânico para a produção de solo fértil. Esse material é utilizado como fertilizante natural pelos produtores da região. Nota-se que o ambiente não apresenta medidas de proteção do solo contra os efeitos do escoamento superficial das águas das chuvas, agravando o processo de erosão laminar e, consequentemente, o assoreamento do córrego. Nesse local, existem diversas nascentes, que irão, posteriormente, desaguar no córrego Cascavel.

\subsection{PROBLEMAS SOCIOAMBIENTAIS}

No contexto deste trabalho, entende-se que problemas socioambientais são alterações ambientais que, direta ou indiretamente, causam danos à qualidade de vida das comunidades. Nesse sentido, na maioria das vezes, os ambientes que apresentam tais problemas estão desequilibrados em virtude das alterações provocadas pelas ações antrópicas.

Nas bacias hidrográficas estudadas, a vegetação nativa é quase inexistente, como consequência do avançado estágio de alteração do uso do solo; apesar de serem ambientes urbanos, predominam as atividades agropastoris. Nota-se que os córregos, antes de desaguarem na área urbana, iá apresentam problemas relacionados à conservação dos ambientes fluviais, pela ausência de matas ciliares e o consequente transporte de sedimentos resultantes da erosão laminar das encostas.

Verificou-se que, na bacia do córrego Maricota, a planície de inundação está sendo alterada de forma a poder impactar o ambiente, causando e/ou intensificando processos de enchentes e polvição dos mananciais, pois há construção de condomínio residencial, pastoreio de bovinos, ausência de mata ciliar e passagem de uma estrada sem pavimentação às margens do curso d'água.

No córrego, após o período de chuvas, ocorre crescimento das plantas aquáticas, aumento da turbidez da água e acúmulo de sedimentos resultantes do processo de erosão laminar, causando o assoreamento do ambiente fluvial. A construção de residências às margens do curso d'água, formando bairros no entorno do córrego, e o processo de ocupação desse ambiente, resultaram na supressão da mata ciliar. Além disso, a proximidade da zona rural faz com que o pastoreio de bovinos seja comum no local. Outro problema socioambiental importante é o lançamento de resíduos sólidos próximo do córrego, causando a polvição do corpo d'água (figura 6). Por ser uma área de lazer muito utilizada pela comunidade, tal situação pode afetar a saúde pública.

As formas suaves do relevo das bacias dos córregos Cascavel e Maricota podem ter sido fatores propícios à ocupação urbana nas APPs. Por isso, devem ser intensificadas a fiscalização e a proteção desses ambientes para que a conservação se sobreponha 
ao uso antrópico. A bacia do córrego Marimbondo, a maior das três, apresenta ocupação residencial nas planícies de inundação e fazendas que desenvolvem atividades agropastoris. Ao contrário dos demais, que formam pequenos lagos antes do reservatório, o córrego Marimbondo deságua diretamente no Lago dos Encantos. As precárias condições ambientais do córrego são evidenciadas pelo forte odor do esgoto e pela ocorrência de vegetação aquática ou semiaquática, de ambientes eutrofizados pela ação antrópica. Tais alterações podem ter intensificado alguns processos naturais comuns nos ambientes fluviais, como as inundações que ocorrem sazonalmente devido às oscilações naturais da vazão dos córregos nos períodos de chuva. Nota-se que muitas áreas estão sendo atingidas por enchentes periódicas em consequência das alterações nas drenagens (figura 6), tanto nas relacionadas à ocupação residencial, deposição de resíduos sólidos e entulhos, quanto nas de retilinização e canalização, como observado no córrego Maricota.

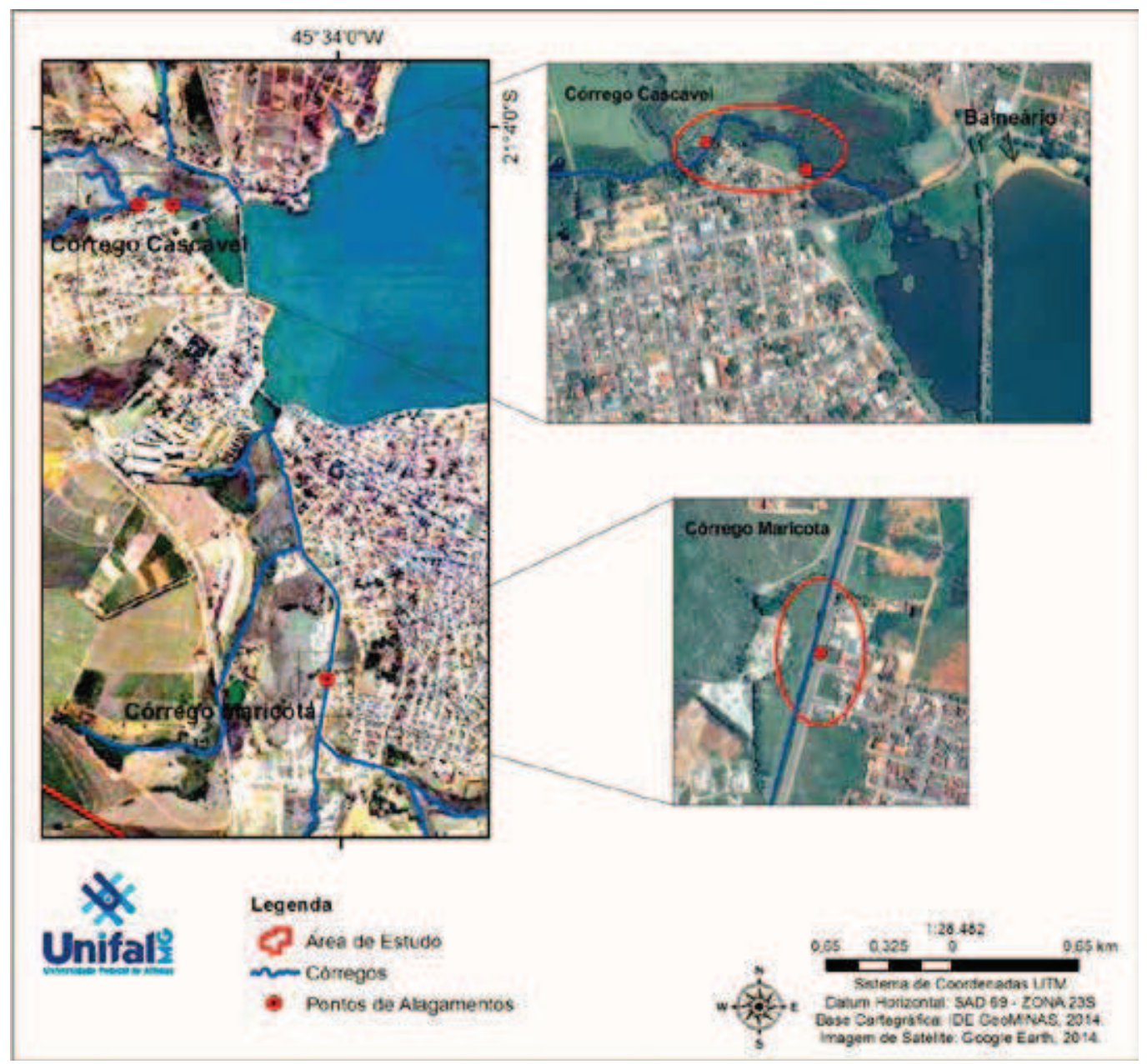

Figura 6 Principais áreas afetadas por enchentes devido às alterações antrópicas nos ambientes fluviais urbanos. Os círculos vermelhos destacam as áreas atingidas por inundações.

Fonte: Clibson Alves dos Santos. A partir de imagens aéreas do Google Earth - 2013. 


\subsection{ANÁLISE DO USO E OCUPAÇÃO DA TERRA}

Por meio da pesquisa ambiental realizada nas drenagens urbanas, constatou-se que os córregos analisados apresentam problemas ambientais, o que se deve, principalmente, à ocorrência da ocupação desordenada em áreas próximas dos cursos d'água. Apesar de as bacias hidrográficas estudadas se encontrarem na área urbana, passam, também, por pequenas propriedades rurais ao longo de seu curso, antes de desaguarem no lago da cidade e, posteriormente, na represa de Furnas.

Para compreender o grau de alteração da cobertura vegetal do perímetro urbano e as alterações nas APPs às margens dos cursos d'água, foi elaborado o Mapa de Uso do Solo (figura 7), a partir da interpretação visual de imagens de alta resolução espacial disponíveis no Google Earth (GOOGLE EARTH, 2013) e da verificação de campo.

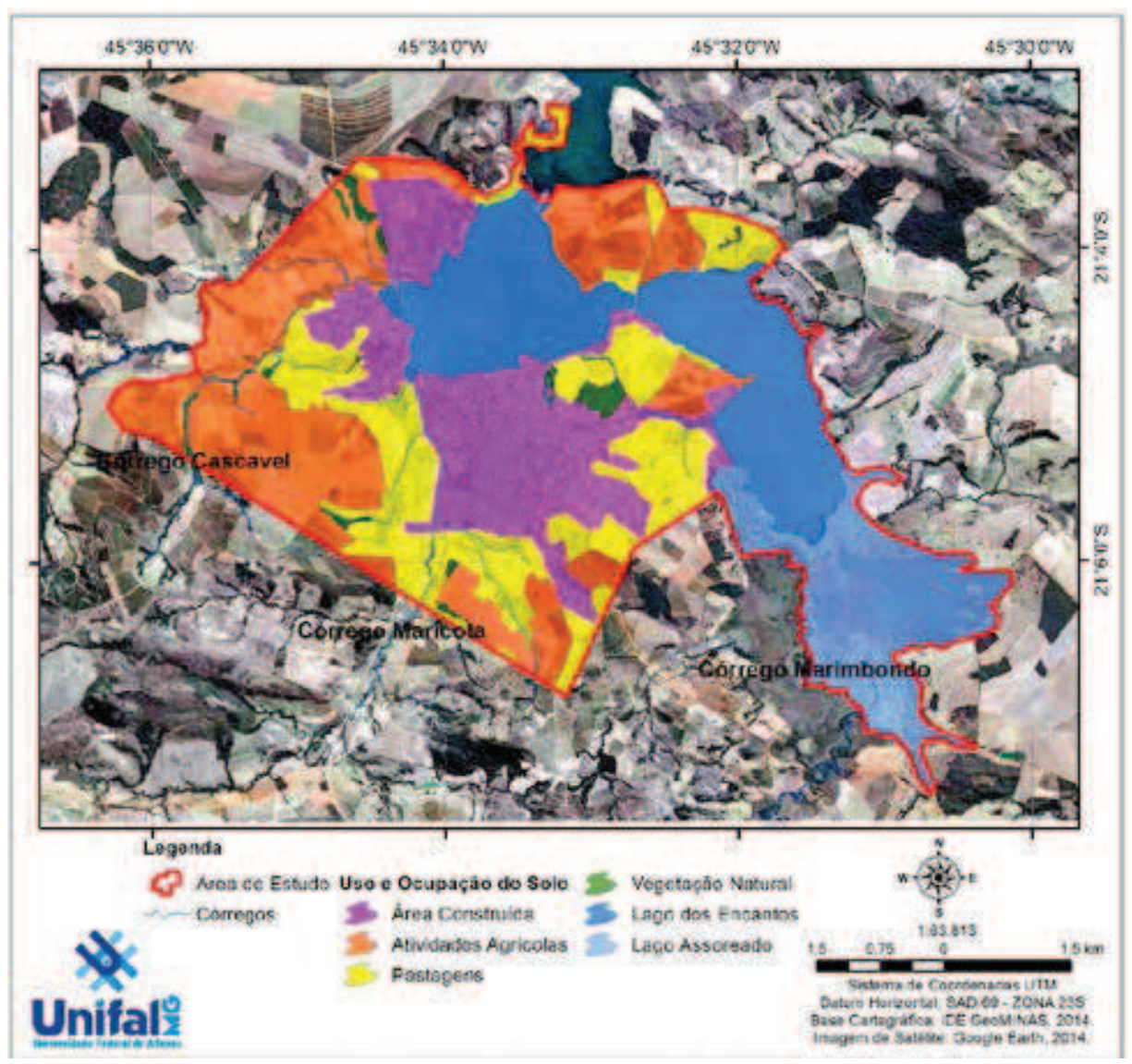

Figura 7 Mapa de Uso e Ocupação da Terra da área de estudo.

Fonte: Clibson Alves dos Santos. A partir de imagens aéreas do Google Earth - 2013.

Por meio desse mapeamento, verificou-se a predominância de atividades agrícolas, principalmente culturas de café, em $95,5 \mathrm{~km}^{2}(26,43 \%)$ do total da área de estudo. As pastagens atingem $71,4 \mathrm{~km}^{2}$ (19,7\%), sendo utilizadas para pastoreio de bovinos em pequena escala. $O$ efeito dessas atividades causa impactos diretos e indiretos nos cursos d'água que se encontram dentro dos limites do perímetro urbano, como o as- 
soreamento associado à erosão laminar, provocado pelo indício do pisoteamento do solo por bovinos. As áreas construídas apresentam uso misto (residencial e comercial), totalizando $68,9 \mathrm{~km}^{2}$ (19\%) da área de estudo.

A área do reservatório pode ser dividida em duas partes: onde a lâmina d'água é visível e utilizada para o lazer da comunidade local e onde a porção do lago se encontra assoreada, totalizando $120,6 \mathrm{~km}^{2}$ (33,3\%). Diante disso, observa-se que restam somente $6,1 \mathrm{~km}^{2}(1,7 \%)$ de vegetação natural, constituída de remanescentes de mata atlântica, evidenciando o problema da falta de áreas verdes e ambientes que apresentem melhor conforto ambiental na área urbana. Essa pequena porcentagem de mata nativa localiza-se nas proximidades do lago, onde se encontra o Parque Florestal Municipal da Sucupira, que possui a fonte d'água denominada como Mina do Ouro (figura 9). O parque tem sido utilizado pelas escolas do município para atividades de educação ambiental, em projetos desenvolvidos pela prefeitura e a Polícia Militar de Meio Ambiente de Minas Gerais.

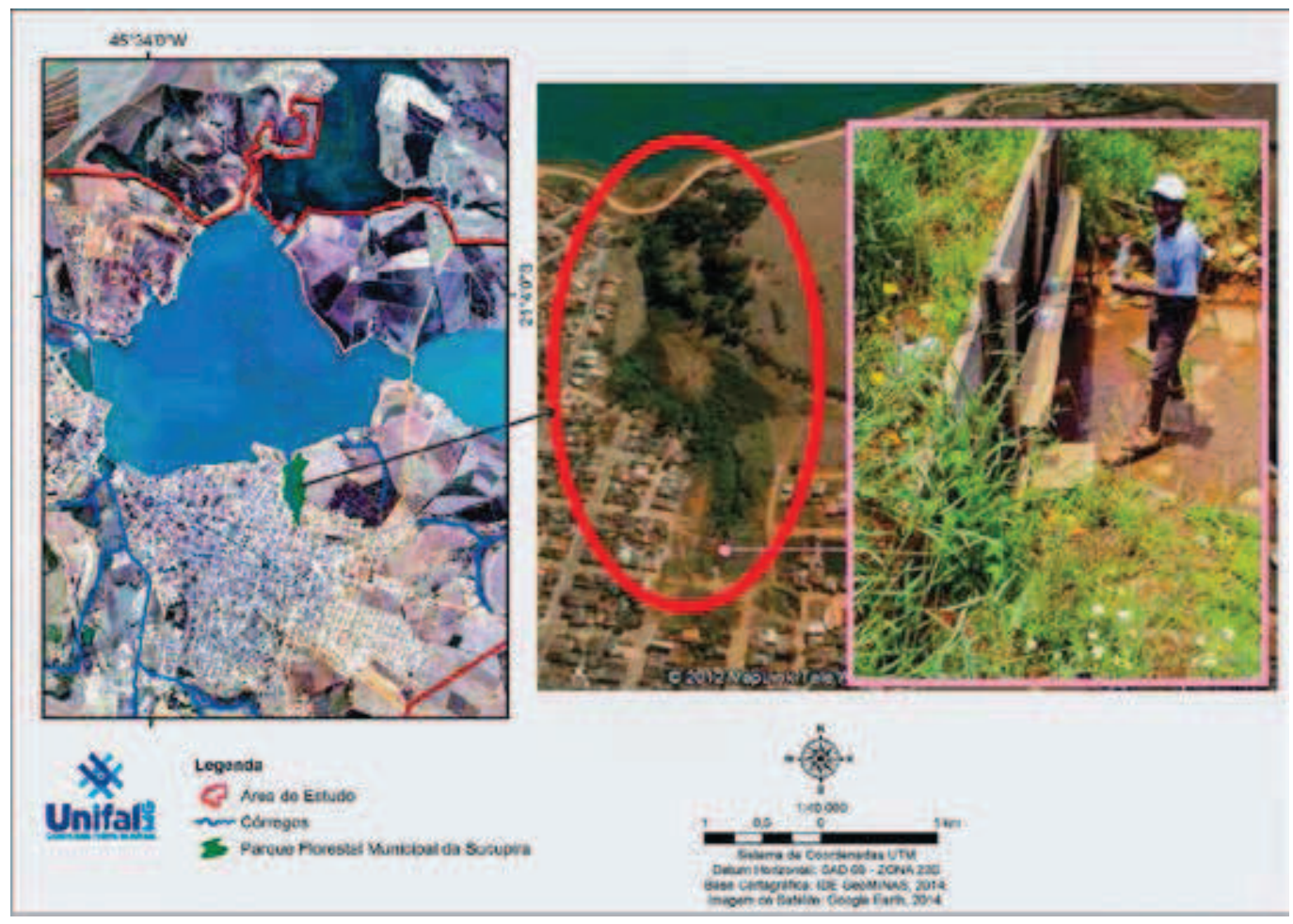

Figura 9 Mina d'água no Parque Florestal Municipal da Sucupira.

Fonte: Clibson Alves dos Santos. A partir de imagens aéreas do Google Earth (2013) e fotos de Larissa Gischewski Guimarães - mar. 2012.

Os córregos Cascavel e Marimbondo apresentam superfície com maior ocorrência de áreas agrícolas, ao contrário do córrego Maricota, onde há predomínio de áreas edificadas. Devido a essas características, é no córrego Maricota onde se registra maior ocorrência de problemas relacionados a enchentes e inundações. Com base no mapa de uso e ocupação do solo (figura 8), procedeu-se à identificação dos usos nas 
APPs, utilizando as ferramentas buffer para delimitar as áreas, e a ferramenta clip para recortar o uso nessas localidades, numa faixa de 30 metros (figura 10), por meio do programa ArcGIS. (ESRI, 2014).

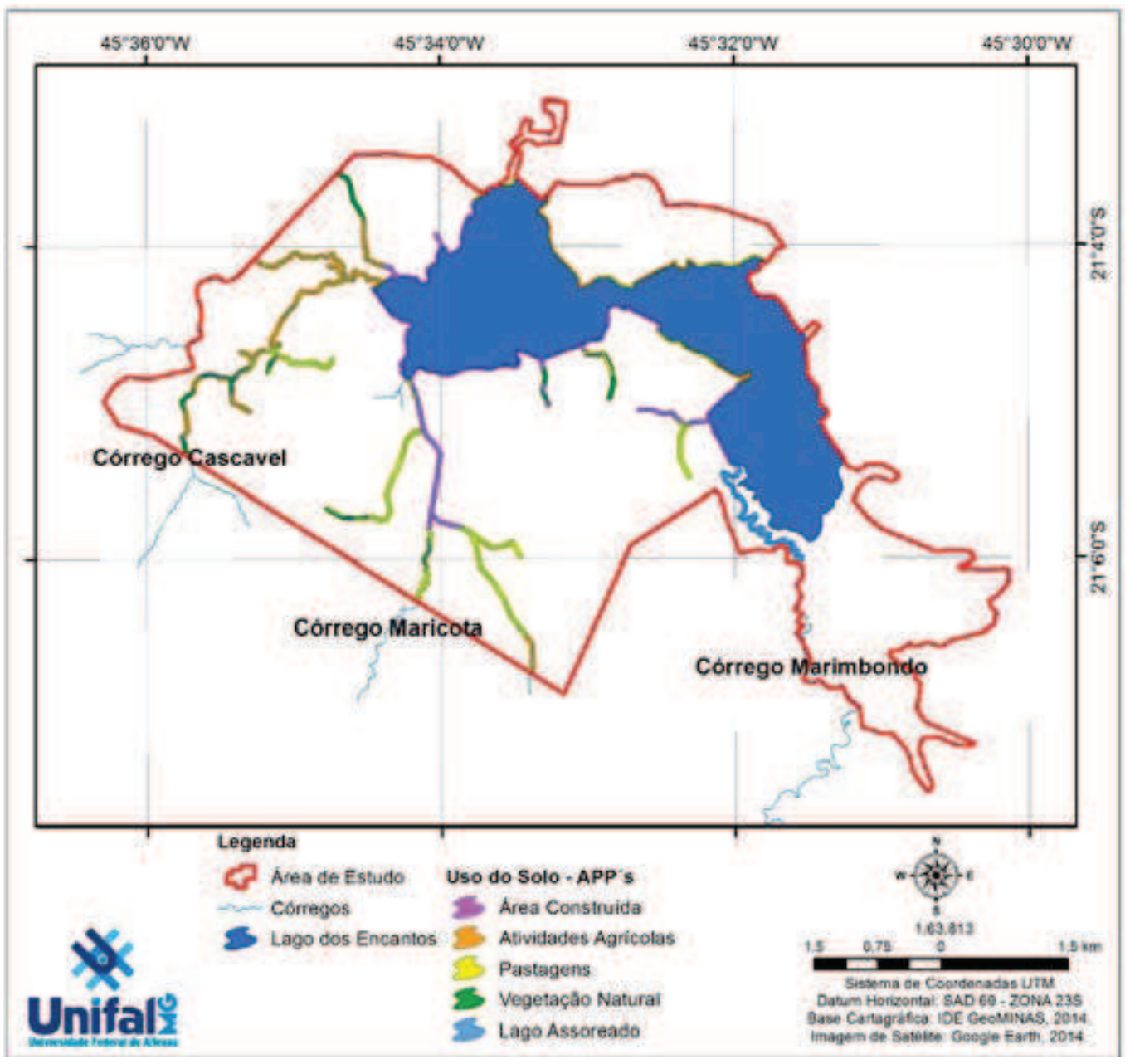

Figura 10 Mapa de delimitação e uso do solo das APPs na área de estudo. Fonte: Clibson Alves dos Santos - 2014

Essa análise possibilita a compreensão das áreas às margens dos córregos que deveriam estar preservadas, mas conforme observado na figura 10 e na tabela 1 , a maior parte dos córregos urbanos encontra-se degradada, com usos incompatíveis com o equilíbrio ecológico dos ambientes fluviais urbanos.

Analisando a figura 10 e a tabela 1, observa-se, também, que as APPs na área de estudo apresentam elevado grau de conflito de uso, isto é, $82 \%$ das áreas que deveriam ter cobertura superficial formada por matas nativas ou vegetação adequada ao ambiente fluvial, são constituídas por atividades agrícolas, pastagens ou edificações. Acrescenta-se a isso o fato de esses ambientes apresentarem diversos indicadores de 
degradação ambiental, conforme já mostrado e discutido. Em relação às bacias, no córrego Maricota predominam os usos do tipo pastagens e áreas construídas; no córrego Cascavel, ocorre predomínio de atividades agrícolas, pastoreio e, em menor escala, há remanescentes de mata nativa. No córrego Marimbondo, as APPs são basicamente constituídas pela área assoreada do lago, que apresenta características pantanosas.

Tabela 1 Uso e Ocupação da Terra na Área de Estudo e nas Áreas de Preservação Permanente às Margens dos Córregos

\begin{tabular}{l|c|c|c|c}
\hline \multirow{2}{*}{\multicolumn{1}{c|}{ Tipo de Uso }} & \multicolumn{2}{c|}{ Área urbana } & \multicolumn{2}{c}{ APPs } \\
\cline { 2 - 5 } & $\mathbf{k m}^{2}$ & $\%$ & $\mathbf{k m}^{2}$ & $\%$ \\
\hline Áreas assoreadas & 46,4 & 12,8 & 1,5 & 8,4 \\
\hline Atividades agrícolas & 95,5 & 26,3 & 4,9 & 27,5 \\
\hline Área construída & 68,9 & 19,0 & 4,5 & 25,3 \\
\hline Vegetação natural & 6,1 & 1,7 & 1,7 & 9,6 \\
\hline Pastagens & 71,4 & 19,7 & 5,2 & 29,2 \\
\hline Lago & 74,2 & 20,5 & - & - \\
\hline Total & 362,7 & 100 & 17,8 & 100 \\
\hline
\end{tabular}

Fonte: Clibson Alves dos Santos - 2014

Enfatiza-se, diante das características dessas áreas, que cada bacia deverá receber um manejo diferente, com projetos de revitalização fluvial condizentes com as interferências antrópicas observadas nessas drenagens, conforme indicações que serão feitas no tópico a seguir.

\section{RECOMENDAÇÕES}

Uma vez realizado o diagnóstico ambiental das bacias hidrográficas urbanas do município de Boa Esperança (MG), propõe-se algumas medidas que visam reduzir e prevenir os impactos ambientais observados nas bacias e sugerir melhorias na qualidade ambiental do entorno do lago e na qualidade de vida para a população. A seguir, serão indicadas ações relacionadas ao planejamento urbano ambiental e à educação ambiental.

\subsection{PLANEJAMENTO URBANO AMBIENTAL}

A melhoria das condições ambientais de qualquer município passa pelo estabelecimento de políticas de planejamento urbano ambiental que respeite as características e as fragilidades naturais dos ambientes, visando melhorar a qualidade ambiental e permitir o uso equilibrado pela sociedade. Para o sucesso desse procedimento será necessário, primeiramente, o investimento em pesquisas sobre os ecossistemas urbanos, considerando funcionamento e manutenção do equilíbrio dinâmico - e, por fim, que 
a implementação de empreendimentos imobiliários ou industriais ocorra com mínima interferência no meio ambiente urbano. É importante agregar a tais projetos e iniciativas uma visão de gestão integrada de recursos naturais, cujo objetivo seja realizar, da maneira mais sustentável possível, o uso e ocupação do solo urbano.

Como parte do planejamento urbano para regularizar a Lei $n^{\circ}$ 12.651/12 (BRASIL, 2012) sobre APPs dos córregos no perímetro urbano, sugere-se a ampliação do Parque Florestal Municipal da Sucupira, agregando um dos principais remanescentes de mata atlântica na área urbana. Para o córrego Maricota, indicam-se as seguintes ações: criação de um parque a ser utilizado para a conservação ambiental e como ambiente de lazer para a comunidade (figura 11); implementação de ciclovia compartilhada com pista de caminhada na avenida Delduque Barbosa; execução de projeto de revegetação com espécies autóctones de mata nativa, ampliando-se os remanescentes observados em pequena escala na região.

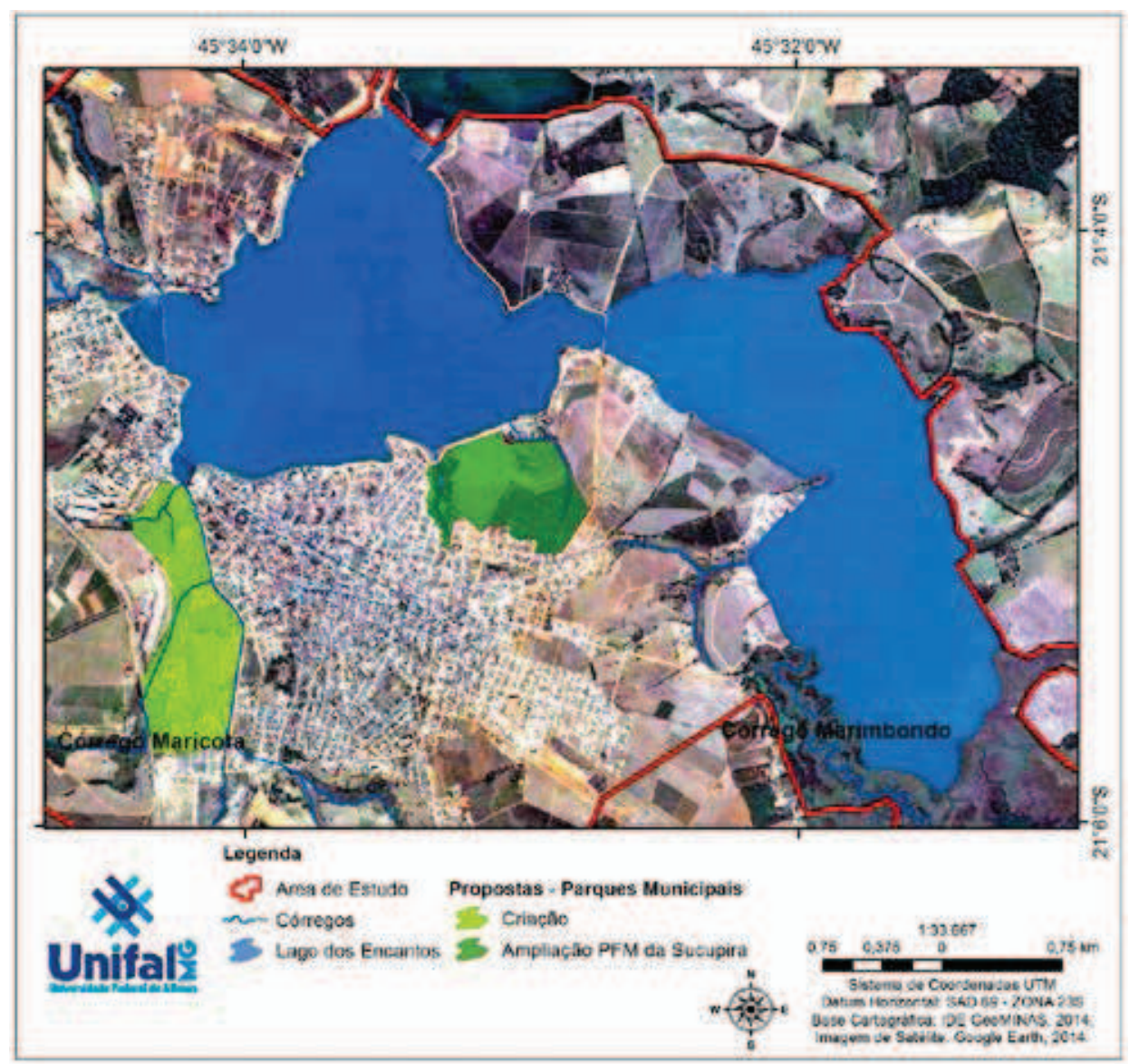

Figura 11 Propostas de criação e ampliação de parques na área de estudo.

Fonte: Clibson Alves dos Santos. A partir de imagens aéreas do Google Earth - 2013.

Outra iniciativa que vem ganhando espaço em referência à ampliação de áreas verdes associadas ao lazer junto da rede hídrica são os parques lineares, que podem ser ferramentas valiosas para limitar a ocupação urbana, ampliar áreas verdes e esti- 
mular o senso de pertencimento das pessoas em relação ao local onde vivem devido a maior apropriação do meio ambiente. A revitalização por meio de parques lineares auxilia, também, o estabelecimento de equilíbrio dinâmico do ambiente fluvial e seria uma boa alternativa para o parque proposto na bacia do córrego Maricota.

Os parques propostos poderiam transformar-se em unidades de conservação de uso sustentável, visando conciliar a preservação da diversidade biológica e dos recursos naturais com o uso sustentável de parte desses recursos, conforme o Sistema Nacional de Unidades de Conservação (SNUC). (BRASIL, 2000). Esses recantos urbanos de preservação contribuiriam com os objetivos conservacionistas de atividade sustentável, tentando conciliar sociedade, ambiente e economia. Essa última vertente da sustentabilidade poderia ser desenvolvida, por exemplo, com a criação de pontos de aluguel de bicicletas entre os parques, ligando os parques e o Lago dos Encantos por meio de ciclovias, o que poderia ser uma ótima rota de turismo ecológico.

A execução dessas iniciativas poderia ser feita com auxílio da iniciativa privada, fundamental para o estabelecimento de um pacto socioambiental para melhorar a qualidade de vida da comunidade local. Tais parcerias podem ser viabilizadas, também, pela inclusão de empresas que tenham passivos ambientais a cumprir - por meio de recursos provenientes, por exemplo, do Termo de Ajustamento de Conduta (TAC), viabilizando projetos de revitalização. Outra fonte de recursos poderia ocorrer por meio de negociações para a aplicação da Lei no 12.503/1997 (MINAS GERAIS, 1997), que criou o Programa Estadual de Conservação da Água, com o objetivo de proteger e preservar os recursos naturais das bacias hidrográficas sujeitas à exploração para abastecimento público ou geração de energia elétrica. Esse instrumento obrigaria as empresas concessionárias de serviços de abastecimento de água e de geração de energia elétrica a investir, no mínimo, 0,5\% do valor total da receita operacional apurada no exercício anterior ao do investimento, na proteção e na preservação ambiental da bacia hidrográfica em que ocorresse a captação.

Para a área mais assoreada do lago, onde deságua o rio Marimbondo, o tratamento necessário seria abranger o controle de erosão a montante (zona rural), dragagem dos sedimentos (desassoreamento) e obras hidráulicas para que cessasse o processo de assoreamento, impedindo a ampliação da área de deposição de sedimentos para outras partes do lago. Posteriormente, como a área que envolve a área mais assoreada do lago é pouco habitada, sugere-se a revegetação das APPs com revegetação por ilhas verdes, uma metodologia de recuperação florestal inserida no conceito de nucleação, constituindo um conjunto diverso de espécies de plantas retiradas de áreas próximo das degradadas para reprodução de um bioma similar. Projetos como o llhas Verdes (IASB, 2014), criado para testar tal metodologia, garante que as ilhas verdes prezam pela diminuição da manutenção dos plantios, o que diminui gastos excessivos e leva a maior efetividade na formação e no desenvolvimento da vegetação fixada.

Ao redor do lago, seria necessária uma análise sobre as formas de contenção de erosão com recomposição vegetal das APPs, sem esquecer as funções socioeconômicas da área - o que poderia causar melhor uso das ruas que circundam o Lago dos 
Encantos, visando melhorar a qualidade ambiental. Outro fator importante seria o melhor aproveitamento turístico do lago, principalmente com a execução de projetos de revitalização das matas ciliares dos córregos urbanos e tratamento do esgoto municipal, o que melhoraria as condições ambientais e os aspectos sanitários das águas urbanas. Sugere-se, ainda, que sejam feitos o mapeamento e a análise de risco de enchentes e inundações no perímetro urbano, visando ao diagnóstico e à proposição de medidas corretivas e preventivas nos fundos de vale. Além disso, o desassoreamento deverá ser realizado na bacia dos córregos Cascavel e Maribondo.

Com o intuito de validar as iniciativas do poder executivo em relação ao uso sustentável dos ambientes urbanos e facilitar o processo de estabelecimentos de parcerias, recomenda-se que, no processo de revisão do Plano Diretor Municipal de Boa Esperança, sejam incluídos instrumentos de conservação ambiental que amparem as propostas presentes neste trabalho.

\subsection{EDUCAÇÃO AMBIENTAL E PARTICIPAÇÃO COMUNITÁRIA}

Pelo fato de o planejamento urbano ambiental possuir objetivo não só de reduzir e prevenir impactos ambientais, mas, também, de melhorar a qualidade de vida da população, torna-se importante que haja o envolvimento da mesma nos assuntos relacionados aos projetos. Além de ter acesso a informações a respeito, a população deve trabalhar em conjunto ao poder público e auxiliar na tomada de decisões, pois é quem mais sofre com os problemas socioambientais resultantes da má gestão do espaço urbano. A participação popular poderia ser realizada por meio de programas de visitas educativas aos parques - com as escolas levando seus alunos para participar de programações de acordo com a faixa etária - ou pela proposição de reuniões públicas para discutir melhorias ambientais e no ordenamento territorial urbano.

Em todo processo de implementação de iniciativas conservacionistas, deve-se estruturar projetos permanentes de educação ambiental, voltados não só para o público escolar, mas também para Organizações Não Governamentais (ONGs), empresas e comunidades direta ou indiretamente atingidas pelos problemas socioambientais aqui descritos. Salienta-se que as ações devem ter caráter estruturante, abrangendo todas as etapas dos projetos, conciliando atividades como oficinas e cursos com ações que envolvam o contato direto com os ambientes, como caminhadas ecológicas, exercícios ao ar livre e outras iniciativas que remetam a uma forma de vida saudável.

\subsection{SÍNTESE DAS RECOMENDAÇÕES}

Segue um quadro síntese com os principais problemas e recomendações propostas para a área de estudo (quadro 2).

Ressalta-se que as sugestões propostas têm como objetivo fomentar o debate sobre possíveis soluções para os problemas observados. A comunidade direta ou indiretamente afetada deve participar do processo decisório, inclusive apontando problemas não observados no presente estudo e propondo novas demandas. $\bigcirc$ poder público 
Quadro 2 Principais Problemas e Recomendações Sugeridas

\begin{tabular}{|c|c|c|}
\hline $\begin{array}{l}\text { Bacias Hidrográficas/ } \\
\text { Entorno do Lago }\end{array}$ & Problemas & Recomendações \\
\hline Córrego Cascavel & $\begin{array}{l}\text { Uso das APPs para a construção } \\
\text { de residências, pastagens e } \\
\text { exploração de solo orgânico; } \\
\text { Assoreamento/eutrofização; } \\
\text { Polvição do curso d'água; } \\
\text { Pontos de inundação. }\end{array}$ & $\begin{array}{l}\text { Despolvição e interrupção do } \\
\text { lançamento de esgoto; } \\
\text { Desassoreamento; } \\
\text { Recomposição vegetal da mata } \\
\text { ciliar; } \\
\text { Fiscalização sobre o uso do } \\
\text { solo; } \\
\text { Mapeamento e análise de risco } \\
\text { de enchentes e inundações; } \\
\text { Projeto de educação } \\
\text { ambiental. }\end{array}$ \\
\hline Córrego Maricota & $\begin{array}{l}\text { Uso das APPs para a construção } \\
\text { de residências, pastagens; } \\
\text { Existência de fábrica de tijolos, } \\
\text { aterros e pontos de inundação. }\end{array}$ & $\begin{array}{l}\text { Recomposição vegetal da mata } \\
\text { ciliar; } \\
\text { Retirada dos aterros } \\
\text { clandestinos; } \\
\text { Fiscalização sobre o uso do } \\
\text { solo; } \\
\text { Mapeamento e análise de risco } \\
\text { de enchentes e inundações; } \\
\text { Criação de Parque Municipal/ } \\
\text { Linear; } \\
\text { Criação de ciclovias; } \\
\text { Projeto de educação } \\
\text { ambiental. }\end{array}$ \\
\hline Córrego Marimbondo & Assoreamento/eutrofização & $\begin{array}{l}\text { Desassoreamento; } \\
\text { Recomposição vegetal da mata } \\
\text { ciliar/revegetação por llhas } \\
\text { Verdes; } \\
\text { Controle de erosão laminar a } \\
\text { montante (zona rural); } \\
\text { Projeto de educação } \\
\text { ambiental. }\end{array}$ \\
\hline Entorno do Lago & Urbanização & $\begin{array}{l}\text { Ampliação do Parque Florestal } \\
\text { Municipal da Sucupira; } \\
\text { Criação de ciclovias; } \\
\text { Projeto de educação } \\
\text { ambiental. }\end{array}$ \\
\hline
\end{tabular}

Fonte: Clibson Alves dos Santos - 2014 
municipal deve mobilizar os diversos seguimentos da sociedade para participar das discussões, propiciando o envolvimento entre os mesmos para estabelecer um pacto social - que envolva, também, a Coordenadoria Regional das Promotorias de Justiça do Meio Ambiente da bacia do rio Grande e as empresas da região.

\section{CONSIDERAÇÕES FINAIS}

$\mathrm{Na}$ área de estudo observou-se que a ação antrópica vem agravando de forma significativa a degradação dos recursos hídricos, causando polvição e assoreamento dos corpos d'água. Outros fatores relacionados ao regime hídrico também são notáveis, como o aumento das vazões, resultante da diminuição da infiltração, que causa a redução dos fluxos subsuperfícies, fundamentais para a recarga do lençol freático e ocorrência das nascentes. Como consequência dessas alterações também ocorre o desequilíbrio biótico dos mananciais, causando danos à saúde pública devido ao aumento das doenças de veiculação hídrica, conforme observado na Bacia Hidrográfica do córrego Cascavel.

Para resolver as questões discutidas, é imperativo que o poder público desenvolva atividades urbanísticas e econômicas de forma planejada, integrando os diversos interesses inerentes às áreas analisadas neste trabalho, visando, sempre, à melhoria das condições e do conforto ambiental no ambiente urbano.

Em relação às ações sugeridas, enfatiza-se a importância do estabelecimento das seguintes ações: coleta e tratamento de esgoto; revitalização dos ambientes fluviais; ampliação das áreas verdes; sistema de gestão ambiental compartilhado pela comunidade, a iniciativa privada, pelas $O N G$ s e pelo poder público. Tais ações devem fazer parte do plano diretor municipal, que precisa ser estruturado considerando as características ambientais e os atrativos naturais do perímetro urbano, para que as diretrizes de uso e ocupação do solo sejam propostas de maneira a valorizar os componentes ambientais.

Espera-se que a caracterização ambiental realizada possa contribuir nas discussões sobre a importância dos aspectos ambientais no ordenamento territorial urbano em Boa Esperança e nos 48 municípios que compõem a Região Hidrográfica do Entorno do Lago de Furnas (GD3). Todos os municípios da região possuem planos diretores (ALAGO, 2014), porém na maioria deles ainda não houve a regulamentação e a estruturação da Lei de Uso do Solo conforme as prerrogativas dos planos. O processo de revisão dessas leis deve ampliar as discussões para que haja integração entre as demandas sociais de ocupação de uso do solo e a melhoria da qualidade ambiental dos municípios. 


\section{REFERÊNCIAS BIBLIOGRÁFICAS}

ASSOCIAÇÃO DOS MUNICÍPIOS DO LAGO DE FURNAS (ALAGO). Plano Diretor, 2014. Disponível em: $<$ http://www.alago.org.br/default.asp?act=pagina\&page=planodiretor_apresentacao >. Acesso em: 5 fev. 2014. BILICH, Marina Rolim; LACERDA, Marilusa Pinto Coelho. Avaliação da qualidade da água do Distrito Federal (DF), por meio de geoprocessamento. In: SIMPÓSIO BRASILEIRO DE SENSORIAMENTO REMOTO, 12, 2005, Goiânia. Anais... INPE, 2005, p. 2059-2065.

BRASIL. Lei Federal n 9.433, de 8 de janeiro de 1997. Institui a Política Nacional de Recursos Hídricos. Diário Oficial da União, 9 jan. 1997, p. 470. Disponível em: <http://www.planalto.gov.br/CCIVIL_03/leis/L9433.htm>. Acesso em: 25 ago. 2015.

BRASIL. Lei Federal n 9.985, de 18 de julho de 2000. Regulamenta o artigo 225, § $1^{\circ}$, incisos I, II, III e VII da Constituição Federal, institui o Sistema Nacional de Unidades de Conservação da Natureza e dá outras providências. Diário Oficial da União, 19 jul. 2000, p. 1. Disponível em: <http://www.mma.gov.br/port/sbf/dap/ doc/snuc.pdf >. Acesso em: 15 abr. 2013.

BRASIL. Lei Federal n $n^{\circ} 1.445$, de 5 de janeiro de 2007. Institui o Plano Nacional de Saneamento Básico. Diário Oficial da União, 8 jan. 2007, p. 3. Disponível em: <http://www.planalto.gov.br/ccivil_03/_ato20072010/2007/lei/l1 1445.htm>. Acesso em: 26 ago. 2012.

BRASIL. Lei Federal n 12.651, de 25 de maio de 2012. Dispõe sobre a proteção da vegetação nativa, e dá outras providências. Diário Oficial da União, 28 mai. 2012, p. 1. Disponível em: <http://www.planalto.gov.br/ ccivil_03/_ato2011-2014/2012/lei/l12651.htm>. Acesso em: 16 abr. 2013.

ESRI. 2014. ArcGIS for Desktop. Versão 10.2. Programa de Computador. Disponível em <http://deskłop.arcgis. com/en/>. Acesso em: 10 jan. 2014.

FELDMANN, Fábio. Guia da ecologia: para entender e viver melhor a relação homem natureza. São Paulo: Abril, 1992. $320 \mathrm{p}$.

GALLI, Corina Sidagis; ABE, Donato Seiji. Disponibilidade, poluição e eutrofização das águas. In: BICUDO, M. Carlos E. de M.; TUNDISI, José Galizia; SCHEUENSTUHL, Marcos C. Barnsley (Org.). Águas do Brasil: análises estratégicas. São Paulo: Instituto de Botânica, 2010. 224 p.

GOOGLE EARTH. 2013. Imagem de Satélite de Boa Esperança (MG). Programa de Computador. Disponível em: <http://earth.google.com>. Acesso em: 15 set. 2013.

INFRAESTRUTURA DE DADOS ESPACIAIS (IDE-GeoMINAS). Base cartográfica vetorial dos Limites PolíticoAdministrativos (Nacional, Estaduais e Municipais). Disponível em: <http://www.ide.ufv.br/geominas/srv/br/main. home >. Acesso em: 15 set. 2014.

INSTITUTO BRASILEIRO DE GEOGRAFIA E ESTATÍSTICA (IBGE). Censo Demográfico 2010: resultados gerais da amostra por áreas de ponderação. Rio de Janeiro: IBGE, 2013. Disponível em: <http://www.ibge.gov.br/ home/estatistica/populacao/censo2010/resultados gerais amostra areas ponderacao/default.shtm>. Acesso em: ago. 2013.

INSTITUTO DAS ÁGUAS DA SERRA DA BODOQUENA (IASB). Projeto Ilhas Verdes, 2014. Disponível em: <http:// www.iasb.org.br/noticia/projeto-ilhas-verdes>. Acesso em: 20 set. 2013.

MERTEN, Gustavo H.; MINELLA, Jean. P. Qualidade da água em bacias hidrográficas rurais: um desafio atual para a sobrevivência futura. Revista Agroecologia e Desenvolvimento Rural, Porto Alegre, v. 3, n. 4, 2002, p.1-7.

MICROSFT. 2013. ICE - Image Composite Editor. Versão 1.4. Programa de Computador. Disponível em:< http:// research.microsoft.com/en-us/um/redmond/projects/ice/>. Acesso em: 15 set. 2013.

MINAS GERAIS. Lei n 12.503, de 30 de maio de 1997. Cria o Programa Estadual de Conservação da Água. Disponível em: <http://www.siam.mg.gov.br/sla/download.pdf?idNorma=627>. Acesso em: 18 jul. 2015.

MOREIRA, Maurício Alves. Fundamentos do sensoriamento remoto e metodologias de aplicação. 3. ed. UFV, 2005. 320 p.

SANTOS, Rozely Ferreira. Planejamento ambiental: teoria e prática. São Paulo: Oficina de Textos, 2004, p. $40-41$.

SCHEUENSTUHL, M. C (Org.). Águas do Brasil: análises estratégicas. São Paulo: Instituto de Botânica, 2010. $224 \mathrm{p}$.

SMITH, Val H.; SCHINDLER, David W. Eutrophication science: where do we go from here? Trends in Ecology and Evolution, 24, p. 201-207. 
Larissa Gischewski Guimarães e Clibson Alves dos Santos

YAHN, Armando Gallo. Água x população: um balanço mundial e regional. Campinas: SEMINÁRIO, SOCIEDADE DE ABASTECIMENTO DE ÁGUA E SANEAMENTO S7A. SANASA, Campinas, 1999, 105 p.

Nota do editor

Submissão: abr. 2015

Aprovação: set. 2015

Paisagem e ambiente: ensaios - N. 36 - São Paulo - P. 69 - 90 - 2015 